\title{
Journal of the American Board of Family Medicine Sixth Annual Practice-based Research Network Theme Issue -They Just Keep Getting Better and Better
}

\author{
Marjorie A. Bowman, MD, MPA, and Anne Victoria Neale, PhD, MPH
}

We have quite a rich issue this month related to practice-based research networks (PBRNs)—reflections on where they have been, where they should go, how they should happen; lessons learned about recruiting physicians and patients and new research methods; and several clinical studies from existing PBRNs. We had an amazing number of manuscripts submitted this year for the PBRN issue; as a result, this is a powerful issue. Some are under revision for future issues of the Journal of the American Board of Family Medicine, just as we have some articles from PBRNs appearing in most issues. PBRNs have deepened the family medicine research tradition. The importance of primary care research to build the evidence base of our clinical practice, plus the useful work building the methods of primary care research, distinguishes the pioneers in PBRNs. PBRNs are Health Improvement Networks and national treasures to be nurtured. (J Am Board Fam Med 2011;24:481-482.)

The issue starts with the idea, proposed by Williams and Rhyne et al, ${ }^{1}$ that the practice-based research networks (PBRNs) have matured and evolved and now really should be thought of as Health Improvement Networks (HITs). This is an idea whose time has come. It is also clearly substantiated by another article from Williams et $\mathrm{al}^{2}$ that shows practice improvement after participation in PBRN studies and can also be seen in other papers in this issue including those by Daly et $\mathrm{al}^{3}$ and Parnes et al. ${ }^{4}$ This improvement has strong face validity in that the process of doing the research and thinking about the topic should help physicians incorporate their research experiences into evidenced-based practice for the benefit of their patients.

The PBRNs have been advanced through the careful nurturing of the Agency for Health Care Research and Quality (AHRQ). David Meyers, a former student of mine (MAB), writes a tribute to Dr. David Lanier, a former faculty colleague of mine (MAB), who pushed the idea of the need for PBRNs at AHRQ. We are truly blessed with such wonderful colleagues. We also appreciate the fact that AHRQ has hosted PBRN national conferences and provided substantial funding both for infrastructure and for the ensuing studies. Nevertheless, improvement is still possible. Pace et $\mathrm{al}^{5}$ critique the current partnership between AHRQ and primary care researchers with propositions for what could further enhance the future of the field.

\section{Clinical Research From PBRNs}

There are several clinical papers from PBRNs; we selected two clusters: pain $(n=2)$ and skin infections $(n=3)$. There is one on low back pain ${ }^{6}$ from a residency research network in Texas and one on chronic pain and the difficulties of its management in practice. ${ }^{7}$ Perhaps not surprisingly, a substantial minority of primary care clinicians in these studies had decided against prescribing narcotics because of the great difficulties related to their prescribing, use, and misuse. The three on skin infections (from Iowa, ${ }^{3}$ from North Carolina, Texas, and Colorado and DARTNet ${ }^{4}$; and again from Texas $^{8}$ ) encompass a large number of groups across the country. Different although similar interventions were associated with increase in appropriate choices for methicillin-resistant Stapbylococcus aureus (MRSA) skin infections. We also include one from Oklahoma9 on whether older patients' assessment of physician quality care is associated with medical outcomes.

\section{The Methods of PBRN}

This section starts with an article on a logic model for PBRN research, ${ }^{10}$ outlining well the multiple 
aspects of the assumptions, inputs, activities, outputs, outcomes, and outcome indicators. The process of creating the logic model also helped the PBRN develop through engagement of the multiple involved parties. Devoe and colleagues ${ }^{11}$ present the amazing work of pulling together a large community health center network that started in Oregon but has expanded and now includes more than 40 safety net organizations serving over 900,000 patients with nearly $8,000,000$ distinct visits. Hamilton et $\mathrm{al}^{12}$ highlight a method for creating efficiency in institutional review board approval for card studies commonly used by PBRNs. We have an article on patient recruitment (small dollar incentives attracted more initial interest but not sustainability ${ }^{13}$ ) and two on physician recruitment (No surprise: Money works better-as does recruitment by a recognized leader/ clinician champion, plus other great hints) from NorTex, a northern Texas primary care PBRN. ${ }^{14,15}$ These "technique" papers include one on getting an unbiased patient sample. ${ }^{16}$ Another highlights two quasi-experimental methods-a stepped-wedge design, and wait-list crossover design-that seem particularly useful in PBRN practices. ${ }^{17}$

This rich-and enriching-issue is our salute to our many PBRN colleagues advancing primary care research in family medicine.

\section{References}

1. Williams RL, Rhyne RL. No longer simply a practice-based research network (PBRN): health improvement networks. J Am Board Fam Med 2011; 24:485-488.

2. Rhyne R, Sussman AL, Fernald D, Weller N, Daniels E, Williams RL. Reports of persistent change in the clinical encounter following research participation: a report from the Primary Care Multiethnic Network (PRIME Net). J Am Board Fam Med 2011; 24:496-502.

3. Daly JM, Levy BT, Ely JW, Swanson K, Bergus GR, Jogerst GJ, Smith TC. Management of skin and soft tissue infections in community practice before and after implementing a "best practice" approach: an Iowa Research Network (IRENE) intervention study. J Am Board Fam Med 2011;24:524-533.

4. Parnes B, Fernald D, Coombs L, et al. Improving the management of skin and soft tissue infections in primary care: a report from State Networks of Colorado Ambulatory Practices and Partners (SNOCAPUSA) and the Distributed Ambulatory Research in Therapeutics Network (DARTNet). J Am Board Fam Med 2011;24:534-542.

5. Pace WD, Fagnan LJ, West DR. The Agency for Healthcare Research and Quality (AHRQ) Practice-
Based Research Network (PBRN) relationship: delivering on an opportunity, challenges, and future directions. J Am Board Fam Med 2011;24:489-492.

6. Young RA, Benold T, Whitham J, Burge S. Factors influencing work interference in patients with chronic low back pain: a Residency Research Network of Texas (RRNeT) study. J Am Board Fam Med 2011;24:503-510.

7. Leverence RR, Williams RL, Potter M, et al. Chronic non-cancer pain: a siren for primary care: a report from the PRImary care MultiEthnic Network (PRIME Net). J Am Board Fam Med 2011;24:551-561.

8. Forcade NA, Parchman ML, Jorgensen JH, et al. Prevalence, severity, and treatment of communityacquired methicillin-resistant Staphylococcus aureus (CA-MRSA) skin and soft tissue infections in 10 medical clinics in Texas: a South Texas Ambulatory Research Network (STARNet) study. J Am Board Fam Med 2011;24:543-550.

9. Mold JW, Lawler F, Schauf KJ, Aspy CB. Does patient assessment of the quality of the primary care they receive predict subsequent outcomes? An Oklahoma Physicians Resource/Research Network (OKPRN) study. J Am Board Fam Med 2011;24:511-523.

10. Hayes H, Parchman ML, Howard R. A logic model framework for evaluation and planning in a primary care practice-based research network (PBRN). J Am Board Fam Med 2011;24:576-582.

11. DeVoe JE, Gold R, Spofford M, et al. Developing a network of community health centers with a common electronic health record: description of the Safety Net West Practice-based Research Network (SNWPBRN). J Am Board Fam Med 2011;24:597-604.

12. Hamilton MD, Cola PA, Terchek JJ, Werner JJ, Stange $\mathrm{KC}$. A novel protocol for streamlined IRB review of practice-based research network (PBRN) card studies. J Am Board Fam Med 2011;24:605-609.

13. Ruffin MT, Nease DE. Using patient monetary incentives and electronically derived patient lists to recruit patients to a clinical trial. J Am Board Fam Med 2011;24:569-575.

14. Fulda KG, Hahn KA, Young RA, et al. Recruiting practice-based research network (PBRN) physicians to be research participants: lessons learned from the North Texas (NorTex) Needs Assessment Study. J Am Board Fam Med 2011;24:610-615.

15. Young RA, Fulda K, Suzuki S, et al. The influence of research compensation options on practice-based research network (PBRN) physician participation: a North Texas (NorTex) PBRN study. J Am Board Fam Me 2011;24:562-568.

16. Logue EE, Bourguet CC. A method for obtaining an unbiased sample of family medicine patients for research purposes. J Am Board Fam Med 2011;24:583-588.

17. Handley MA, Schillinger D, Shiboski S. Quasi-experimental designs in practice based research settings: design and implementation considerations. J Am Board Fam Med 2011;24:589-596. 